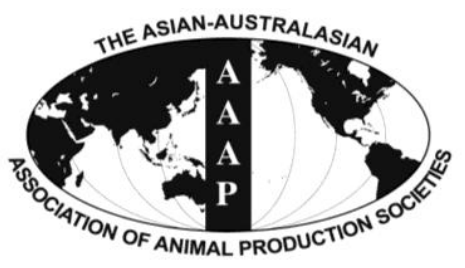

Asian Australas. J. Anim. Sci.

Vol. 26, No. 7 : 911-915 July 2013

http://dx.doi.org/10.5713/ajas.2013.13018

www.ajas.info

pISSN 101 1-2367 elSSN 1976-5517

\title{
Effects of CSN1S2 Genotypes on Economic Traits in Chinese Dairy Goats
}

\author{
X. P. Yue, Q. Fang, X. Zhang' ${ }^{1}$ C. C. Mao, X. Y. Lan, H. Chen, and C. Z. Lei* \\ Shaanxi Key Laboratory of Molecular Biology for Agriculture, College of Animal Science and Technology, \\ Northwest A\&F University, Yangling, Shaanxi 712100, China
}

\begin{abstract}
The aim of this study was to investigate allele frequencies at the CSN1S2 locus in two Chinese dairy goat breeds and the effects of its variation on dairy goat economic traits. Seven hundred and eight goats from Xinong Saanen (XS, $\mathrm{n}=268)$ and Guanzhong (GZ, N = 440) breeds were selected. The milk samples of 268 XS goats were collected during the middle of lactation, body size parameters (708 goats) and daily milk yield (202 goats) were registered. The RFLP (restriction fragment length polymorphism) and SSCP (single strand conformation polymorphism) were used to detect the polymorphisms in CSN1S2. The Hardy-Weinberg (HW) equilibrium and the associations between body size, milk yield and composition and the genotypes were calculated. The results revealed that only A and F CSN1S2 alleles were found in the two Chinese dairy goat breeds. Allelic frequencies of A and F were $0.795,0.205$ and 0.739, 0.261 in Xinong Saanen and Guanzhong population respectively. Xinong Saanen breed was in Hardy-Weinberg equilibrium, while Guanzhong breed deviated from Hardy-Weinberg equilibrium $(\mathrm{p}<0.05)$. The association of polymorphism with economic traits indicated that the goats with FF genotype have higher milk fat and total solid concentration than those with AA and AF genotypes (p<0.05). (Key Words: CSN1S2, SNP, Dairy Goats, Milk, A and F Alleles)
\end{abstract}

\section{INTRODUCTION}

Casein genes are organized as a cluster, including in order $\alpha_{\mathrm{S} 1}$-casein $(C S N 1 S 1), \alpha_{\mathrm{S} 2}$-casein (CSN1S2), $\beta$-casein $(C S N 2)$ and $\kappa$-casein (CSN3) (Ferretti et al., 1990; Threadgill and Womack, 1990). In goats, the entire casein cluster region spans about $250 \mathrm{~kb}$ on chromosome 6 (Hayes et al., 1993). In recent years, the genetic polymorphism of goat casein has raised considerable research interest because goat casein polymorphisms are related to milk quality, milk composition and technological properties (Martin et al., 2002).

The CSNIS2 gene is $18.5 \mathrm{~kb}$ long and consists of 18 exons which vary from 21 to $266 \mathrm{bp}$ (Groene et al., 1993). Seven alleles, showing three different synthesis levels, have been identified so far. The A, B, C, E and F alleles are characterized by point mutations related to single amino acid substitutions and associated with a normal amount of $\alpha \alpha_{S_{2}-\text { casein }}(2.5 \mathrm{~g} / \mathrm{L})$. The CSN1S2 B allele, compared to the A allele, shows a G10A transition at exon 9, which

\footnotetext{
* Corresponding Author: Chuzhao Lei. Tel: +86-29-87091090, Fax: +86-29-87092164, E-mail: leichuzhao1118@126.com

1 Liaoning Agricultural Vocational \& Technical College, Department of animal husbandry, Yingkou, 115009, China. Submitted Jan. 6, 2013; Accepted Mar. 12, 2013; Revised Mar. 21, 2013
}

causes a Glu64 $\rightarrow$ Lys substitution in the mature protein, while the mutational events characterizing the $\mathrm{C}$ and $\mathrm{E}$ variants are substitution A5T (Lys167 $\rightarrow$ Ile) and C83G (Pro193 $\rightarrow$ Arg) at exon 16, respectively (Bouniol et al., 1994). The CSNIS2 F allele is characterized by a G13C transition occurring at exon 3 , which results in an amino acid substitution Val7 $\rightarrow$ Ile (Bouniol et al., 1994; Veltri et al., 2000 Ramunno et al., 2001a). CSN1S2 D is a rare defective allele characterized by a deletion, involving part of the exon 11 and of the following intron. The null allele CSNIS2 O associated with a non-detectable amount of this casein fraction shows a $\mathrm{G} \rightarrow \mathrm{A}$ transition at the 80th nucleotide in exon 11, creating a premature stop codon at position 110 (Ramunno et al., 2001a).

China, with nearly four million goats, is one of largest producers of dairy goats in the world. Among which, the Xinong Saanen (SN) and Guanzhong (GZ) breeds are the best-known, not only due to their tolerance of crushed feed and the local harsh weather, but also to their high milk yield (Xu et al., 2003; Deng et al., 2010). While as for Chinese dairy goats, we found few reports about studying DNA polymorphism and their association with economic traits. The aim of the present study was to investigate the genetic structure of CSNIS2 locus in these two important Chinese dairy goat breeds. Therefore, the genetic variations analysis 
Table 1. The primer pair sequences and their information of CSN1S2 gene in goat

\begin{tabular}{llccc}
\hline Loci & \multicolumn{1}{c}{ Sequences of primers } & Annealing temperature & Amplified region/size bp & Allele \\
\hline L1 & R: 5'-TCTCTTGCCATCAAAACA-3' & 50.4 & $\begin{array}{c}\text { Exon3 and flanking } \\
\text { region/310 bp }\end{array}$ & F \\
L2 & F: 5'-TGGTCTTTATTCCTCTCT-3' & R:5'-GGACTCTAAATATACTTAATGAATT-3' & 54.8 & Exon9 and flanking \\
region/261 bp & B \\
& F: 5'-GCTTATCGTCCACAGTAATCTT-3' & & Exon11 and partial & O, D \\
L3 & R: 5'-GACACATAGAGAAGATTC-3' & 50.6 & intron11/301 bp & C, E \\
& F: 5'-CGTTGGGACATTTTATCT-3' & & Exon16 and flank & region/226 bp \\
\hline
\end{tabular}

Numbering of L2 and L4 loci primers agrees with the nucleotide sequence of goat CSN1S2 gene (GenBank No. AJ297310 and AJ297315).

of the CSN1S2 gene in 708 Chinese dairy goats may provide useful information related to the understanding of their genetic characteristics. The genetic associations related to goat milk yield and composition in Chinese dairy goat breeds will possibly contribute to improving the quality of dairy goat breeds in China.

\section{MATERIALS AND METHODS}

\section{Samples collection and DNA extraction}

Blood samples of 708 goats were collected from two Chinese dairy goat breeds of Xinong Saanen (XS) and Guanzhong breed (GZ) as follows: Qianyang Dairy Goat Breeding Farm (XS breed, $\mathrm{n}=202$ ), Northwest A\&F University Goat Farm (XS breed, $\mathrm{n}=66$ ) and Shaanxi Dairy Goat Breeding Centre (GZ breed, $\mathrm{n}=440$ ) in Sanyuan county, Shaanxi province of China. The genomic DNA was extracted from blood by a standard phenolchloroform method (Chomczynski and Sacchi, 1987).

\section{Milk samples and data collection}

The milk yield of second lactation of the XS breed $(n=$ 202) in Qianyang Dairy Goat Breeding Farm was recorded. In addition, a $50 \mathrm{ml}$ sample of morning milk obtained from goats of the XS breed in Northwest A\&F University Goat Farm and Qianyang Dairy Goat Breeding Farm was collected $(\mathrm{n}=268)$. The milk samples were stored at $4{ }^{\circ} \mathrm{C}$ until the next day when they could be analyzed by MilkoScan FT120 (FOSS Corporation, Denmark) for concentrations of milk fat, protein, lactose, total solids (TS), milk solids-not-fat (SNF) and density of milk. Body size parameters of all goats are documented, including Withers height, Body length and Chest circumference.

\section{Genotyping of CSN1S2 locus}

CSN1S2 F, O and D Alleles were detected by means of RFLP-PCR (restricted fragment length polymorphismPCR) according to Ramunno et al. (2001a). Furthermore, based on the nucleotide sequence characterization of CSN1S2 B, C and E alleles, the PCR-SSCP procedure was developed for genotyping them by analyzing polymorphisms of exon 9 and exon 16 of CSN1S2 gene (Table 1). The PCR-SSCP and RFLP-PCR procedures were carried out based on Yue et al. (2011) and Ramunno et al. (2001a) respectively.

\section{Statistical analysis}

Genotypic and allelic frequencies, as well as HardyWeinberg equilibriums, were directly calculated. Mixed model analyses for milk yield, milk composite and body size parameters were performed using the general linear models procedure of SSPS 17.0 (SPSS Inc., Chicago, IL, USA). The model for dairy goats included marker genotype, year, kidding season (spring versus fall) and lactation number as fixed effects, the linear and quadratic effects of milk yield, milk composite and body size parameters included as covariables and doe as a random effect. The factor, number of kids, had not been included in the statistical model for following reason. The ewes in this study predominantly had one kid, but does that produced twins were also part of the dataset. Data were presented as least squares means with associated standard error.

\section{RESULTS AND DISUSSION}

The CSN1S2 locus is characterized by the presence of seven alleles, of which, A, B, C, E and F are associated with normal $\alpha_{\mathrm{s} 2}$-casein level $(2.5 \mathrm{~g} / \mathrm{L})$. D allele is associated with reduced $\alpha_{2}$-casein content, and $\mathrm{O}$ allele is associated with a non-detectable amount of this casein in milk (Ramunno et al., 2001a, b). Interestingly, in present study only CSN1S2 F and A alleles were detected (Figure 1), while B, C, E, D and $\mathrm{O}$ alleles were absent. Overall, three different genotypes, AA, AF and FF were identified in the two Chinese dairy goat breeds. Allele and genotype frequencies are shown in the Table 2. Frequencies of A and F alleles in XS and GZ breeds are $0.795 / 0.205$ and $0.739 / 0.261$, respectively. XS breed was found to follow the Hardy-Weinberg equilibrium, whereas GZ breed was deviated from Hardy-Weinberg equilibrium $(\mathrm{p}<0.05)$. Associations of second lactation milk yield, body size and milk composition and genotype were calculated by SPSS 17.0 (Table 3). Statistical analysis 

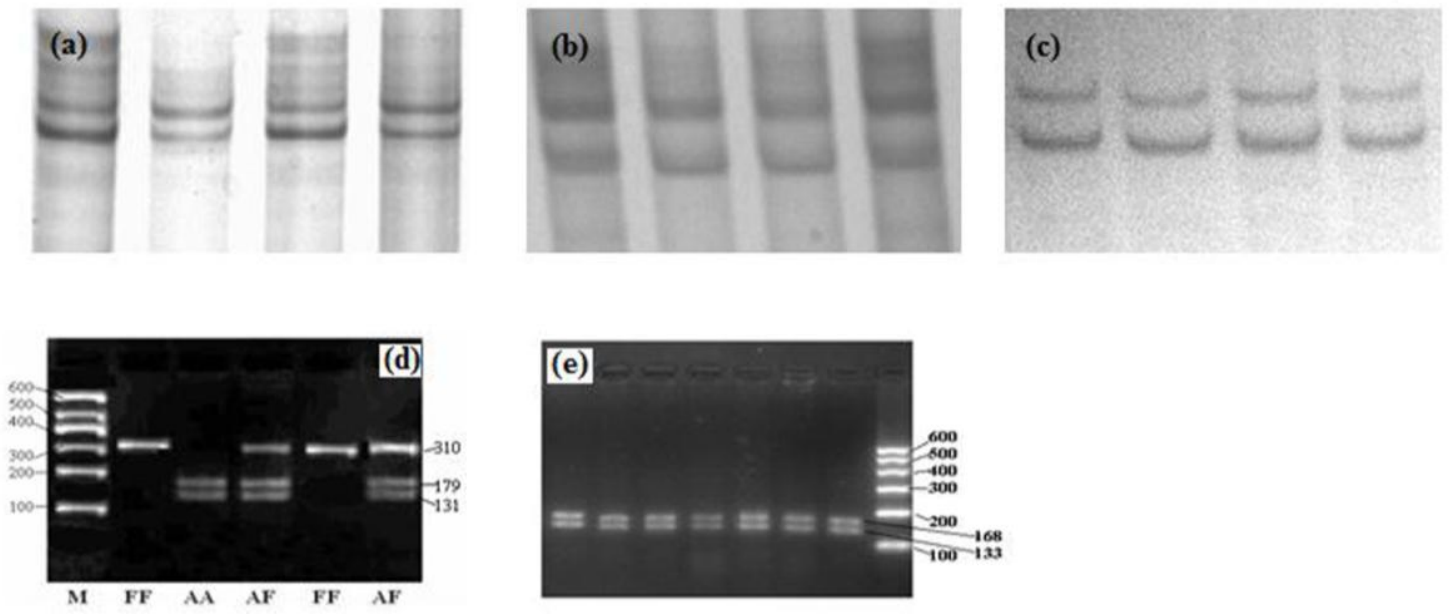

Figure 1. PCR products of five loci analyzed by PCR-SSCP and PCR-RFLP. Figure 1-a, b, c are the PAGE-electrophoresis patterns of PCR-SSCP for L1 (a), L3 (b), L5 (c) locus of CSN1S2 gene, respectively. They all show monopolymorphy. Figure 1-d is the 2.5\% agarose gel electrophoresis for Alw26 I digesting PCR products of CSN1S2 L2 locus. Figure 1-e is the 2.5\% agarose gel electrophoresis for Nco I digesting PCR products of CSN1S2 L4 locus.

indicated that the individuals with FF genotype have higher milk fat and total solid than those of AA and AF genotypes. However, this mutation has no influence on milk yield and body size parameters based on the current study (Table 3). Previous study revealed that dairy goats with CSN1S2 FF genotype had a significantly lower milk yield than other individuals, whereas this study did not show that goats carrying FF genotype had a significantly lower milk yield
(Lan et al., 2005). This can be explained by the sample size of the previous study being too small (69 individuals).

It is interesting that only two CSN1S2 alleles (A and F allele) were detected in two Chinese dairy goat breeds in the present study, which is greatly different from the CSN1S2 allelic distribution in European dairy goat breeds. The frequency of CSN1S2 A, B and C alleles were estimated to be $0.85,0.04$ and 0.11 in French Alpine and Saanen breeds

Table 2. Genotype and allelic frequencies of CSN1S2 gene in 2 dairy goat breeds

\begin{tabular}{|c|c|c|c|c|c|c|c|c|c|c|}
\hline \multirow{2}{*}{ Breeds } & \multicolumn{3}{|c|}{ Genotypes } & \multirow{2}{*}{$\frac{\text { Samples }}{\mathrm{N}}$} & \multicolumn{3}{|c|}{ Genotype frequencies } & \multicolumn{2}{|c|}{ Allele frequencies } & \multirow{2}{*}{$x^{2}$} \\
\hline & AA & $\mathrm{AF}$ & FF & & $\mathrm{P}_{\mathrm{AA}}$ & $\mathrm{P}_{\mathrm{AF}}$ & $\mathrm{P}_{\mathrm{FF}}$ & $\mathrm{A}$ & $\mathrm{F}$ & \\
\hline $\mathrm{XS}$ & 170 & 86 & 12 & 268 & 0.634 & 0.321 & 0.045 & 0.795 & 0.205 & 0.071 \\
\hline GZ & 250 & 150 & 40 & 440 & 0.568 & 0.341 & 0.091 & 0.739 & 0.261 & $6.029 *$ \\
\hline
\end{tabular}

Value with $* *$ and $*$ differ significantly at $\mathrm{p}<0.01$ and $\mathrm{p}<0.05$ respectively. $2 . x_{0.05}^{2}(\mathrm{df}=1)=3.84, x_{0.01}^{2}(\mathrm{df}=1)=6.63$.

Table 3. Associations of polymorphism at CSN1S2 gene L2 locus with economic traits in dairy goats

\begin{tabular}{lccc}
\hline \multirow{2}{*}{ Traits } & \multicolumn{3}{c}{ Genotypes } \\
\cline { 2 - 4 } & AA & AF & FF \\
\hline Fat $(\%)$ & $2.71 \pm 0.12^{\mathrm{a}}$ & $2.69 \pm 0.19^{\mathrm{a}}$ & $3.86 \pm 0.42^{\mathrm{b}}$ \\
Protein (\%) & $3.25 \pm 0.05$ & $3.20 \pm 0.08$ & $3.43 \pm 0.18$ \\
TS (\%) & $11.29 \pm 0.15^{\mathrm{a}}$ & $11.18 \pm 0.23^{\mathrm{a}}$ & $12.57 \pm 0.52^{\mathrm{b}}$ \\
SNF (\%) & $8.48 \pm 0.06$ & $8.38 \pm 0.23$ & $8.61 \pm 0.20$ \\
Lactose (\%) & $4.12 \pm 0.03$ & $4.06 \pm 0.47$ & $4.04 \pm 0.10$ \\
Density (g/L) & $1,030.84 \pm 0.23$ & $1,030.26 \pm 0.38$ & $1029.69 \pm 0.78$ \\
Milk yield (kg) & $860.90 \pm 33.20$ & $825.54 \pm 13.43$ & $822.79 \pm 8.48$ \\
Withers height (cm) & $70.99 \pm 0.35$ & $71.27 \pm 0.41$ & $71.42 \pm 0.79$ \\
Body length (cm) & $80.03 \pm 0.44$ & $80.18 \pm 0.69$ & $79.66 \pm 1.18$ \\
Chest circumference (cm) & $91.98 \pm 2.62$ & $94.05 \pm 2.98$ & $93.68 \pm 5.17$
\end{tabular}

Values in the same row labeled with the different letter $(a, b)$ are significantly different.

The number of goats carrying AA, AF and FF genotypes with body size parameters (Withers height, Body length and Chest circumference) represent 420 , 236 and 52 individuals, respectively.

In milk composite traits (Fat, Protein, TS, SNF, Lactose, and Density), AA, AF and FF genotypes represent 170, 86 and 12 individuals, respectively. In the milk yield, $\mathrm{AA}, \mathrm{AF}$ and $\mathrm{FF}$ genotypes represent 139, 54 and 9 individuals, respectively. 
before discovering the E, D, F and $\mathrm{O}$ alleles (Bouniol et al., 1994). While $C$ and $F$ alleles are predominant in local Italian goat breeds (Sacchi et al., 2005). The relatively high incidence of $\mathrm{O}$ allele $(0.146)$ appeared in Hungarian Milking Goats (Kusza et al., 2007). There needs to be a larger number of Chinese dairy goats and more goat breeds sampled to confirm whether CSN1S2 alleles in addition to A and $\mathrm{F}$ exist in Chinese goat breeds.

A previous study (Ramunno et al., 2001a) reported that CSN1S2 homozygous genotypes were associated with good quality of milk proteins. We also detected this tendency, but this difference was not significant $(\mathrm{p}>0.05)$, maybe due to the small sample size. This study indicated that $\mathrm{F}$ allele was associated with good quality of milk fat. According to this finding, the selection of goats with higher milk fat should aim to increase the homozygous CSN1S2 FF genotype.

The defective $\mathrm{D}$ and $\mathrm{O}$ alleles were not identified in this study. Both alleles showed a very low or null frequency in previous studies (Sacchi et al., 2005; Marletta et al., 2005; Kusza et al., 2007). The results of the trial allow us to presume that the CSN1S2 genetic polymorphism in the two Chinese breed does not affect the $\mathrm{a}_{\mathrm{s} 2}$-casein quantity. CSN1S2 locus is closely linked to CSN1S1, CSN2 and CSN3 loci and alleles of these loci are inherited together as allele groups called haplotype (Hayes et al., 1993; Rijnkels, 2002). It means that polymorphisms occurring at a casein locus have to be considered in the context of the casein gene cluster, using information deriving from the entire casein haplotype (Hayes et al., 2006; Finocchiaro et al., 2008). The goats analyzed in this study showed the occurrence of defective alleles at the CSN1S1 locus, coding for $\alpha s_{1}$-casein, such as the $\mathrm{F}, 01$ and $\mathrm{N}$ alleles in our previous studies (Yue et al., 2011). Therefore further studies are required to determine the relationship between the absence of CSN1S2 D and CSN1S2 O alleles and the distribution of alleles at CSN1S1, CSN2 and CSN3 loci in the populations studied.

\section{ACKNOWLEDGEMENTS}

This work was supported by the National "863" Program of China (No.2008AA10Z138), National Natural Science Foundation of China (No.31172184), and Natural Science Foundation of Shaanxi province of China (No.2011JQ3009).

\section{REFERENCES}

Bouniol, C., G. Brignon, M. F. Mahé, and C. Printz. 1994. Biochemical and genetic analysis of variant $C$ of caprine $\alpha s_{2}$ casein (Capra hircus). Anim. Genet. 25:173-177.

Chomczynski, P., and N. Sacchi. 1987. Single-step method of RNA isolation by acid guanidinium thiocyanate-phenolchloroform extraction. Anal. Biochem. 162:156-159.
Deng, C. J., R. N. Ma, X. P Yue, X. Y. Lan, H. Chen, and C. Z. Lei. 2010. Association of IGF-I gene polymorphisms with milk yield and body size in Chinese dairy goats. Genet. Mol. Biol. 33:266-270.

Ferretti, L., P. Leone, and V. Sgaramella. 1990. Long range restriction analysis of the bovine casein genes. Nucleic Acids Res. 18:6829-6833.

Finocchiaro, R., B. J. Hayes, M. Siwek, R. J. Spelman, J. B. C. H. M. van Kaam, T. Ådnøy, and B. Portolano. 2008. Comparison of casein haplotypes between two geographically distant European dairy goat breeds. J. Anim. Breed. Genet. 125:68-72.

Groenen, M. A., R. J. M. Dijkhof, A. J. M. Verstege, and J. J. Van der Poel. 1993. The complete sequence of the gene encoding bovine $\alpha s_{2}$-casein. Gene 123:187-193.

Hayes, B., N. Hagesæther, T. Ådnøy, G. Pellerud, P. R. Berg, and S. Lien. 2006. Effects on production traits of haplotypes among casein genes in Norwegian goats and evidence for a site of preferential recombination. Genetics 174:455-464.

Hayes, H., E. Petit, C. Bouniol, and P. Popescu. 1993. Localization of the alpha S2-casein gene (CASAS2) to the homologous cattle, sheep and goat chromosomes 4 by in situ hybridization. Cytogenet. Cell Genet. 64:281-285.

Kusza, S., G. Veress, S. Kukovics, A. Jávor, A. Sanchez, A. Angiolillo, and A. Bősze. 2007. Genetic polymorphism of $\alpha_{s 1}$ and $\alpha_{\mathrm{s} 2}$-caseins in Hungarian milking goats. Small Rumin. Res. 68:329-332.

Lan, X. Y., H. Chen, R. F. Zhang, Y. Tian, Y. D. Zhang X. T. Fang, W. B. Sun, C. Z. Lei, and S. R. Hu. 2005. Association of polymorphisms of CSN1S2 gene with average milk yield and body sizes indexes in Xinong Saanen dairy goat. Acta Veterinaria Et Zootechnica Sinica 36:318-322 (in Chinese).

Marletta, D., S. Bordonaro, A. M. Guastella, A. Criscione, and G. D'Urso. 2005. Genetic polymorphism of the calcium sensitive casein in Sicilian Girgentana and Argentata dell'Etna goat breeds. Small Rumin. Res. 57:133-139.

Martin, P., M. Szymanowska, L. Zwierzchowski, and C. Leroux. 2002. The impact of genetic polymorphisms on the protein composition of ruminant's milks. Reprod. Nutr. Dev. 42:433459.

Ramunno, L., G. Cosenza, M. Pappalardo, E. Longobardi, D. Gallo, N. Pastore, P. Di Gregorio, and A. Rando. 2001a. Characterization of two new alleles at the goat CSN1S2 locus. Anim. Genet. 32:264-268.

Ramunno, L., E. Longobardi, M. Pappalardo, A. Rando, P. Di Gregorio, G. Cosenza, P. Mariani, N. Pastore, and P. Masina. 2001b. An allele associated with a non-detectable amount of $\alpha_{\mathrm{s}}$-casein in goat milk. Anim. Genet. 32:19-26.

Rijnkels, M. 2002. Multispecies comparison of the casein gene loci and evolution of casein gene family. J. Mammary Gland Biol. Neoplasia 7:327-345.

Sacchi, P., S. Chessa, E. Budelli, P. Bolla, G. Ceriotti, D. Soglia, R. Rasero, E. Cauvin, and A. Caroli, 2005. Casein haplotype structure in five Italian goat breeds. J. Dairy Sci. 88:1561-1568.

Threadgill, D. W., and J. E. Womack. 1990. Genomic analysis of the major bovine milk proteins genes. Nucleic Acids Res. 18: 6935-6942.

Veltri, C., R. Lagonigro, E. Pietrolà, M. D'Andrea, F. Pilla, and L. Chianese. 2000. Molecular characterization of the goat $\alpha_{\mathrm{s} 2}-$ casein $\mathrm{E}$ allele and its detection in goat breeds of Italy, in: 
Proceedings 7th International Conference on Goats, Tour, Yue, X. P., X. M. Zhang, W. Wang, R. N. Ma, C. J. Deng, X. Y. France, 15-18 May, p. 727.

Xu, G. Y., J. B. Pu, and T. Y. Chen. 2003. On development status and countermeasures of goat industry in western China. China Herbivores Suppl. 1:31-32. Lan, H. Chen, F. Li, X. R. Xu, Y. Ma, and C. Z. Lei. 2011. The CSN1S1 $\mathrm{N}$ and F alleles identified by PCR-SSCP and their associations with milk yield and composition in Chinese dairy goats. Mol. Biol. Rep. 38:2821-2825. 